\title{
In Situ Redox Manipulation Treatability Test —Waste Management Plan
}

Date Published

February 1997

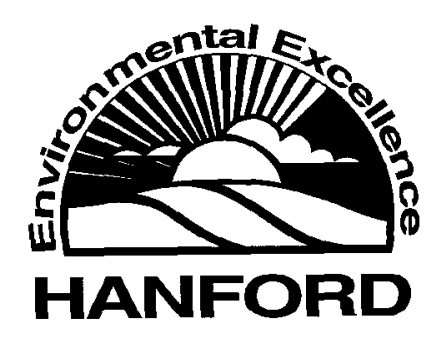

Prepared for the U.S. Department of Energy

Office of Environmental Restoration and

Waste Management

Bechtel Hanford, Inc.

Richland, Washington 
TRADEMARK DISCLAIMER

Reference herein to any specific commercial product, process, or service by trade name, trademark, manufacturer, or otherwise, does not necessarily constitute or imply its endorsement, recommendation, or favoring by the United States Government or any agency thereof or its contractors or subcontractors.

This report has been reproduced from the best available copy. Available in paper copy and microfiche.

Available to the U.S. Department of Energy

and its contractors from

Office of Scientific and Technical Information

P.O. Box 62

Oak Ridge, TN 37831

(615) $576-8401$

Available to the public from the U.S. Department of Commerce

National Technical Information Service

5285 Port Royal Road

Springfield, VA 22161

(703) $487-4650$

Printed in the United States of America

DISCLM-5.CHP (8-91) 


\section{CONTENTS}

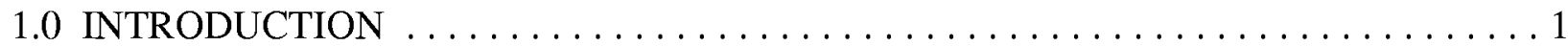

2.0 DESCRIPTION $\ldots \ldots \ldots \ldots \ldots \ldots \ldots \ldots \ldots \ldots \ldots \ldots \ldots \ldots \ldots \ldots \ldots \ldots$

3.0 CONTAMINATION/FIELD SCREENING $\ldots \ldots \ldots \ldots \ldots \ldots \ldots \ldots \ldots \ldots \ldots \ldots$

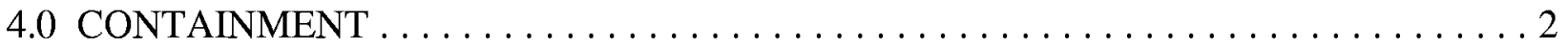

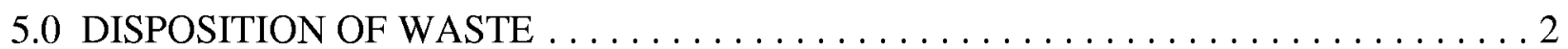

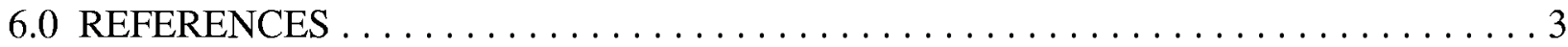

\section{ATTACHMENT}

ISRM Estimated New Well Locations $\ldots \ldots \ldots \ldots \ldots \ldots \ldots \ldots \ldots \ldots \ldots$ 
BHI-00986

Rev. 0

\subsection{INTRODUCTION}

This Waste Management Plan (WMP) provides guidance for the management of waste generated from groundwater well installations in the $100-\mathrm{HR}-3$ Operable Unit (OU). The well installations are necessary to implement the In Situ Redox Manipulation (ISRM) Treatability Test to determine methods for in situ remedial efforts to prevent discharge of hexavalent chromium at levels above those considered protective of aquatic life in the Columbia River and riverbed sediments.

This WMP meets the substantive requirements for a Site Specific Waste Management Instruction as detailed in BHI-EE-02, Environmental Requirements.

\subsection{DESCRIPTION}

Twelve wells are currently scheduled for installation in the $100-\mathrm{HR}-3 \mathrm{OU}$ in support of the ISRM. All wells will be installed near Hanford Site well 199-D4-1 (Attachment 1). The wells will be used for injection of chemical agents, monitoring of processes, and extraction of remediated groundwater. The injection, monitoring, and extraction activities associated with this treatability test are not covered by this WMP.

\subsection{CONTAMINATION/FIELD SCREENING}

Soil contamination is not anticipated during borehole advancement. Based on existing groundwater monitoring data, radiological contaminants are not expected in the soils; nonradiological contaminants are also not expected (with the potential exception of chromium). As a precautionary measure, soil piles will be surveyed for radioactivity a minimum of once each day soils are added to the pile. Measurements will be made by a radiological control technician (RCT) using hand-held screening instruments.

Filtered groundwater will be tested for contaminants when the wells first reach the water table. Samples will be analyzed for hexavalent chromium by Hach kit to verify contamination levels. The groundwater generated during well drilling (that exceeds release criteria of $80 \mathrm{ug} / \mathrm{L}$ hexavalent chromium) will be stored for future treatment in the 100-HR-3 IRM pump-and-treat system. Based on these analyses, groundwater will either be contained for treatment or disposed of on the ground surface.

Because a substantial quantity of analytical data exists for locales where the wells will be installed, formal laboratory soil or groundwater analyses for chemical and radiological characterization will not be performed during the drilling activity. Soils are not anticipated to contain concentrations of chromium that will exceed the toxic characteristic leach procedure 
BHI-00986

Rev. 0

levels for hazardous/dangerous waste designation $(5 \mathrm{mg} / \mathrm{L}$ in the leachate). The clean criteria for total chromium in soils is $18.5 \mathrm{mg} / \mathrm{kg}$ ( $\mathrm{ppm}$ ) based on Hanford Site background values and is $8 \mathrm{mg} / \mathrm{kg}$ for hexavalent chromium based on groundwater protection. No other groundwater constituents have been identified that would designate the soils as radioactive, characteristic, or listed dangerous waste.

\subsection{CONTAINMENT}

Drilling spoils will be accumulated in piles near the point of generation. If the groundwater must be contained, the spoils will be placed on plastic to prevent any residual, free groundwater from being released to the soil. Groundwater draining from spoil piles will be contained as described below.

Contaminated groundwater, above release limits, that is generated during well drilling will be contained in a portable tank and will subsequently be transferred to the approved storage containers described below.

Containment of decontamination rinsate will not be required, providing that downhole tools and equipment are wiped down to remove residual material prior to steam cleaning. The wiping must be sufficient to remove any solid contaminants that could conceivably show up in the rinsate. The subsequent steam cleaning will use potable water only (with no additives).

Groundwater will be contained, when required, in steel 209- L (55-gal) open head drums or other approved water tank or tanker truck. The following information is to be written or posted on the container with indelible contrasting ink and maintained in legible condition until processed:

Label containers of water as follows:

C Project name and contents (e.g., 100-HR-3 ISRM Pump and Treat Process Feed Water)

C Reason for containment (e.g., hexavalent chromium concentrations exceed 80 ppb release criteria)

C Contact information: (e.g., Contact [name of field superintendent and phone number] for additional information).

\subsection{DISPOSITION OF WASTE}

Groundwater should be the only waste generated requiring extended management. All groundwater that is contained will be processed at a future date through the $100-\mathrm{HR}-3$ IRM pump-and-treat system. Soil piles will be leveled following well installation. Purgewater shall be managed in accordance with $\mathrm{BHI}-\mathrm{EE}-01$. 
Miscellaneous trash items (e.g., rags, wipes, disposable personal protective equipment, etc.) will be nonregulated and disposed as such. Should radiological or chemical contamination be encountered, regulated waste would be contained and disposed of appropriately; however, this situation is not expected.

\subsection{REFERENCES}

BHI, 1996, Environmental Investigations Procedures 1.1, "Purge Water Management," BHI-EE-01, Volume 1, Bechtel Hanford, Inc., Richland, Washington.

BHI, 1996, Environmental Requirements, Section 12, "Waste Management Program Requirements," BHI-EE-02, Bechtel Hanford, Inc., Richland, Washington.

BHI, 1996, Field Support Waste Management Instructions W-006, "Site Specific Waste Management Instructions," BHI-FS-03, Bechtel Hanford, Inc., Richland, Washington. 


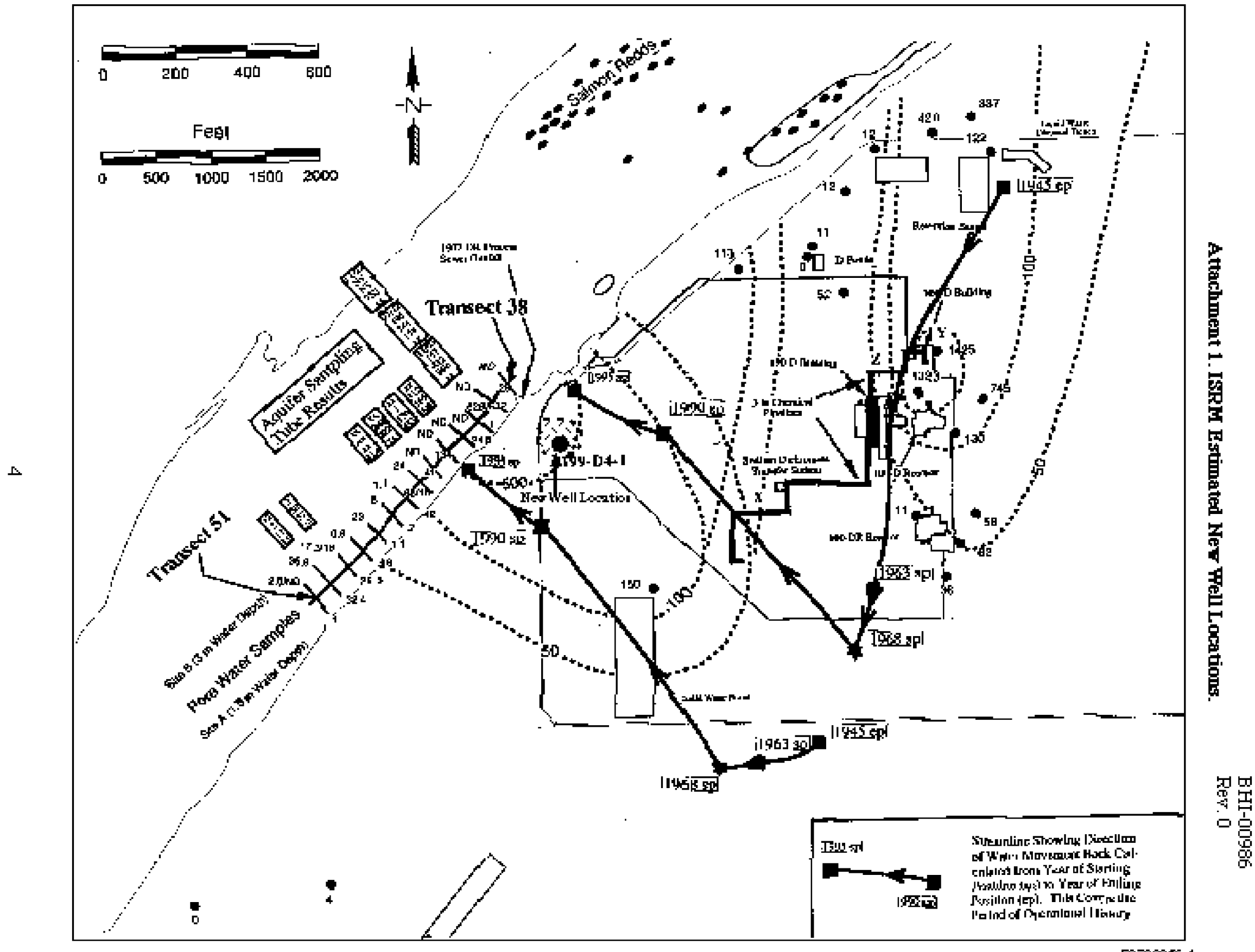

E9000\% 1 